Revista Brasil. Bot., V.32, n.1, p.155-163, jan.-mar. 2009

\title{
Dispersal modes and fruiting periods in hyperseasonal and seasonal savannas, central Brazil
}

\author{
IGOR AURÉLIO SILVA', MARCUS VINICIUS CIANCIARUSO ${ }^{1}$ and \\ MARCO ANTÔNIO BATALHA ${ }^{1}$
}

(received: February 28, 2008; accepted: January 20, 2009)

\begin{abstract}
Dispersal modes and fruiting periods in hyperseasonal and seasonal savannas, central Brazil). Seasonal savannas are characterized by an intense drought that influences their functioning. Hyperseasonal savannas experience additionally a waterlogging during the rainy season. In South America, the largest savanna environment is the Brazilian cerrado. To assess whether a particular dispersal mode or fruiting period is associated to the waterlogging, we examined dispersal and phenological groups in hyperseasonal and seasonal cerrado plant species. We compared the proportion of species and individuals in these groups with G-tests for independence in contingency tables. We did not find differences in the proportion of species; however, based on the proportion of individuals, the main dispersal strategy was anemochory in the hyperseasonal cerrado and zoochory in the seasonal cerrado. Phenological strategies of fruiting in safe periods of the year were differently selected in both cerrados. In the hyperseasonal cerrado, most individuals fruited in non-waterlogged periods, whereas in the seasonal cerrado, most individuals fruited in wetter periods. Thus, waterlogging may drive important modifications in the efficiency of the dispersal and phenological strategies of hyperseasonal savannas plants.
\end{abstract}

Key words - cerrado, dispersal modes, guilds, phenology, waterlogging

RESUMO - (Modos de dispersão e períodos de frutificação em savanas hiperestacional e estacional, Brasil central). Savanas estacionais são caracterizadas por uma seca pronunciada que influencia seu funcionamento. Savanas hiperestacionais passam adicionalmente por alagamento na estação chuvosa. Na América do Sul, a maior região de savana é o cerrado. Para avaliar se um modo particular de dispersão ou um período de frutificação está associado ao alagamento, examinamos grupos de dispersão e fenológicos em espécies presentes em cerrados hiperestacional e estacional. Comparamos a proporção de espécies e indivíduos nesses grupos com testes $\mathrm{G}$ para independência em tabelas de contingência e não encontramos diferenças na proporção de espécies em ambos os grupos. No entanto, com base na proporção de indivíduos, a anemocoria foi a principal estratégia de dispersão no cerrado hiperestacional e a zoocoria, no cerrado estacional. Estratégias fenológicas de frutificação nos períodos mais seguros do ano foram diferentemente selecionados em ambos os tipos de cerrado. No cerrado hiperestacional, a maioria dos indivíduos frutificou nos meses não alagados, enquanto que, no cerrado estacional, a maioria dos indivíduos frutificou nos meses úmidos. Portanto, o alagamento pode promover importantes modificações na eficiência das estratégias de dispersão e fenológicas de plantas de savanas hiperestacionais.

Palavras-chave - alagamento, cerrado, fenologia, guildas, modos de dispersão

\section{Introduction}

Waterlogging plays an important role in determining plant distribution in terrestrial communities (Visser et al. 2003), since the consequences to plants may be fatal (Nicol et al. 2003). Waterlogging ceases plant aerobic respiration, causing a dramatic decline in levels of energyrich adenylates, ion uptake, and transport (Huang et al. 2003, Vartapetian et al. 2003). Even if a short period of waterlogging does not kill the plants, it has considerable long-term effects on plant growth (Malik et al. 2002),

\footnotetext{
1. Universidade Federal de São Carlos, Departamento de Botânica, Caixa Postal 676, 13565-905 São Carlos, SP, Brazil.

2. Universidade Federal de Goiás, ICB, Departamento de Biologia Geral, Caixa Postal 131, 74001-970 Goiânia, GO, Brazil.

3. Corresponding author: igor6cordas@yahoo.com.br
}

reducing the competitive abilities of species (Jackson \& Drew 1984). Thus, by causing local extinctions of intolerant species, waterlogging is expected to define the species composition in local assemblages (Nicol et al. 2003).

Seed dispersal and fruiting period are vital for survival and regeneration of plant populations (Schaik et al. 1993, Ozinga et al. 2004). They are related to colonization ability of the plants and contribute to reduce competitive exclusion (Tilman 1997, Nathan \& MullerLandau 2000). As environmental conditions constrain the availability and efficiency of individual diaspores (Tackenberg et al. 2003, Ozinga et al. 2004), differences in the predominance of dispersal modes and fruiting periods are expected among plant communities. In this sense, anemochory and autochory have been related to dryer and disturbed environments; zoochory, to more 
stable ones (Ozinga et al. 2004); and fruiting period, to water availability in savannas (Sarmiento 1983, Batalha \& Martins 2004). Consequently, seed dispersal and fruiting period have important implications to community structuring.

Seasonal savannas are characterized by a sharp seasonality, in which the water shortage defines community functioning (Sarmiento 1983). Hyperseasonal savannas, however, experience additionally a waterlogging period in the rainy season (Sarmiento 1983). In South America, the largest savanna region is the Brazilian cerrado (Ratter et al. 1997). The vegetation of the hyperseasonal cerrado presents structural changes throughout the year that may motivate differences in the proportion of dispersal modes and fruiting periods when compared to the vegetation of the seasonal cerrado. Waterlogging and drought exclude seasonally species from the hyperseasonal cerrado community, opening up space for colonization of other species (Cianciaruso et al. 2005). These structural changes in vegetation are expected to increase the dispersal potentials for anemo and autochorous species (Ozinga et al. 2004), as well as favour the fruiting periods in seasons of mesic soil conditions (Cianciaruso et al. 2005). As a consequence, ecological differences between hyperseasonal and seasonal cerrado species may be related to dispersal and phenological strategies.

In general, hyperseasonal savannas are among the least comprehended vegetation forms of the world (Kier et al. 2005), and few studies in the Neotropics deal directly with ecological strategies of the hyperseasonal savanna plants (see Sarmiento 1983 for references). In this study, we examined how the hyperseasonal and seasonal cerrado plants are distributed in dispersal and fruiting phenological groups. To determine whether a particular dispersal mode and fruiting period are associated to different environments, we assessed the proportion of species and individuals in these groups. Therefore, we addressed a main question: Does waterlogging select species with different dispersal modes and fruiting periods in a hyperseasonal cerrado when compared to a seasonal cerrado?

\section{Material and methods}

We carried out this study in Parque Nacional das Emas, one of the largest and most important natural reserves in the cerrado region. The Parque Nacional das Emas is located in the Brazilian Central Plateau, southwestern Goiás State, and comprises 132,941 ha. We sampled a hyperseasonal cerrado (approximately, 18 $18^{\circ} 07^{\prime} \mathrm{S}, 52^{\circ} 57^{\prime} 56^{\prime \prime} \mathrm{W}$ ) and a nearby seasonal cerrado (approximately, $18^{\circ} 17^{\prime} 34^{\prime \prime} \mathrm{S}$, $52^{\circ} 58^{\prime} 12^{\prime \prime}$ W) in five surveys from February 2003 to February 2004, comprising all seasons. Both areas presented similar physiognomies (Batalha et al. 2005), i.e., grasslands, with the predominance of herbs and few scattered shrubs and trees. The most abundant species in the hyperseasonal and seasonal cerrados are, respectively, the grasses Andropogon leucostachyus Kunth. and Tristachya leiostachya Nees. We delimited a 1 ha area, placing randomly ten $1 \mathrm{~m}^{2}$ quadrats in each field trip and counting the number of individuals of each vascular plant species, excepting seedlings (i.e., species with cotyledons). In the case of ceaspitose grasses and sedges, we considered the whole tuft as an individual. Thus, the total sampling effort in each vegetation form was $50 \times 1 \mathrm{~m}^{2}$ plots. The sampling sufficiency was obtained with the first four surveys. We classified the plant species according to the classification of flowering plant of the Angiosperm Phylogeny Group (2003). For a more detailed description of the studied areas and sampling methods, see Batalha $e t$ al. (2005), Cianciaruso et al. (2005), and Silva \& Batalha (2006).

We used data from all surveys to establish the proportion of species and individuals in dispersal groups (DGs) and in fruiting phenological groups (FPGs). We excluded the nonidentified species to genus level from the analyses. We established the dispersal mode of each species into five major groups, according to Pijl's (1972) morphological criteria: anemochory, autochory, endozoochory, synzoochory, and epizhoochory. We classified the species according to the seemingly most important mode of dispersion, not including secondary dispersal, such as myrmechory and saurochory. When the diaspores were not observed, we classified the dispersal mode according to the literature (Batalha \& Mantovani 2000, Gottsberger \& Silberbauer-Gottsberger 2006). To assess whether the proportions of species and individuals in DGs in both cerrados were different $(\alpha=0.05)$, we applied the G-test for independence in contingency tables (Sokal \& Rohlf 1995).

We classified the sampled species into FPGs based on phenological data from "Parque Nacional das Emas" (Batalha \& Martins 2004). We established four FPGs: 1. 'late rainy season', for species fruiting from January to April; 2. 'dry season', for species fruiting from May to August; 3. 'early rainy season', for species fruiting from September to December; and 4. 'whole year', for species fruiting throughout the year. We classified the species with fruiting periods lasting more than five months in two FPGs, since their seeds may arrive in both periods. These FPGs were based in the expected soil water availability along the year in savannas (Cianciaruso et al. 2005): 1. During the late rainy season, water is available in the seasonal cerrado soil, while the hyperseasonal cerrado experiences a waterlogging period; 2 . In the dry season, both vegetation forms experience a drought period; 3 . In the early rainy season, water is available for plants in both cerrados. We also applied the G-test (Sokal \& Rohlf 1995) to assess whether the proportions of species and individuals in FPGs were different in the cerrados $(\alpha=0.05)$. 


\section{Results}

We sampled 2,377 individuals, belonging to 72 species, in the hyperseasonal cerrado, and 3,382 individuals, belonging to 121 species, in the seasonal cerrado (table 1). We excluded from all analyses eight unknown species found in the hyperseasonal cerrado (comprising 24 individuals or $1.0 \%$ of the total sampled) and 12 unknown species found in the seasonal cerrado (comprising 55 individuals or $1.6 \%$ of the total sampled). We also excluded from the FPGs evaluation one species found in the hyperseasonal cerrado and six species found in seasonal cerrado (table 1), because their fruiting periods were not observed by Batalha \& Martins (2004). The proportion of species in DGs were not different (figure $1, \mathrm{G}=5.518, P=0.238$ ). In the hyperseasonal

Table 1. Species, number of individuals, dispersal mode, and fruiting periods in the hyperseasonal cerrado (HC) and seasonal cerrado (SC), Parque Nacional das Emas, central Brazil. (GF = growth form; Disp = main dispersal mode; ane = anemochorous; auto = autozoochorous; endo = endozoochorous; epi = epizoochorous; syn = synzoochorous; Late = late rainy season $(\mathrm{January}-$ April); Dry = dry season (May-August); Early = early rainy season (September-December); $1=$ fruiting; $0=$ not fruiting). We classified the species into growth forms according to Cornelissen et al. (2003).

\begin{tabular}{|c|c|c|c|c|c|c|c|}
\hline Family/Species & $\mathrm{HC}$ & $\mathrm{SC}$ & GF & Disp & Late & Dry & Early \\
\hline \multicolumn{8}{|l|}{ AMARANTHACEAE } \\
\hline Froelichia procera (Seub \& Mart.) Pedersen & 1 & 12 & herb & ane & 1 & 1 & 0 \\
\hline Pfaffia helichrysoides (Mart.) Kuntze & 1 & 4 & herb & ane & 0 & 1 & 1 \\
\hline \multicolumn{8}{|l|}{ ANACARDIACEAE } \\
\hline Anacardium humile A. St-Hil. & & 6 & shrub & syn & 0 & 0 & 1 \\
\hline \multicolumn{8}{|l|}{ ANNONACEAE } \\
\hline Annona crassiflora Mart. & 1 & 16 & tree & endo & 1 & 0 & 1 \\
\hline Annona warmingiana Mello-Silva \& Pirani & & 5 & shrub & endo & 0 & 0 & 1 \\
\hline \multicolumn{8}{|l|}{ ARECACEAE } \\
\hline Allagoptera campestris (Mart.) Kuntze & 15 & 14 & herb & syn & 1 & 0 & 1 \\
\hline Attalea geraensis Barb. Rodr & & 1 & herb & syn & 1 & 1 & 1 \\
\hline Syagrus flexuosa (Mart.) Becc. & 27 & 37 & herb & syn & 1 & 1 & 1 \\
\hline \multicolumn{8}{|l|}{ ASTERACEAE } \\
\hline Aspilia foliacea Baker & & 3 & herb & ane & 1 & 0 & 1 \\
\hline Aspilia leucoglossa Malme & & 5 & herb & ane & 0 & 0 & 1 \\
\hline Calea clausseniana Baker & & 2 & herb & ane & 0 & 0 & 1 \\
\hline Calea cuneifolia DC. & & 5 & herb & ane & 0 & 0 & 1 \\
\hline Chromolaena squalida (DC.) R. M. King \& H. Rob. & 7 & 1 & shrub & ane & 0 & 1 & 1 \\
\hline Elephantopus biflorus (Less.) Sch. Bip. & & 1 & herb & aut & 1 & 0 & 0 \\
\hline Emilia coccinea (Sims.) G. Don & 1 & & herb & ane & 1 & 1 & 0 \\
\hline Erechtites hieraciifolius (L.) Raf. ex DC. & 3 & & herb & ane & 1 & 1 & 1 \\
\hline Eupatorium campestre DC. & 1 & 46 & herb & ane & 1 & 1 & 1 \\
\hline Vernonia herbacea (Vell.) Rusby & & 2 & herb & ane & - & - & - \\
\hline Wedelia macedoi $\mathrm{H}$. Rob. & & 2 & herb & aut & - & - & - \\
\hline \multicolumn{8}{|l|}{ BIGNONIACEAE } \\
\hline Anemopaegma arvense (Vell.) Stellfeld \& J. F. Souza & & 1 & shrub & ane & 0 & 0 & 1 \\
\hline Tabebuia ochracea (Cham.) Standl. & & 8 & tree & ane & 0 & 0 & 1 \\
\hline \multicolumn{8}{|l|}{ BURSERACEAE } \\
\hline Protium ovatum Engl. & & 2 & shrub & endo & 0 & 1 & 1 \\
\hline \multicolumn{8}{|l|}{ CELASTRACEAE } \\
\hline Tontelea micrantha (Mart. ex Schult.) A. C. Sm. & 5 & 21 & shrub & endo & 0 & 0 & 1 \\
\hline \multicolumn{8}{|l|}{ CONNARACEAE } \\
\hline Rourea induta Planch. & & 5 & shrub & endo & 1 & 0 & 1 \\
\hline \multicolumn{8}{|l|}{ CONVOLVULACEAE } \\
\hline Ipomoea procurrens Meisn. & 1 & 1 & herb & aut & 1 & 0 & $\begin{array}{c}0 \\
\text { continue }\end{array}$ \\
\hline
\end{tabular}


continuation

\begin{tabular}{|c|c|c|c|c|c|c|c|}
\hline Family/Species & $\mathrm{HC}$ & $\mathrm{SC}$ & GF & Disp & Late & Dry & Early \\
\hline \multicolumn{8}{|l|}{ CYPERACEAE } \\
\hline Bulbostylis junciformis (Kunth.) C. B. Clarke & & 4 & herb & aut & 1 & 0 & 0 \\
\hline Cyperus meyenianus Kunth & 1 & & herb & aut & 1 & 0 & 0 \\
\hline \multicolumn{8}{|l|}{ DILLENIACEAE } \\
\hline Davilla elliptica A. St-Hil. & & 11 & shrub & endo & 1 & 1 & 1 \\
\hline \multicolumn{8}{|l|}{ EBENACEAE } \\
\hline Diospyros hispida DC. & 2 & 32 & tree & endo & 1 & 0 & 1 \\
\hline \multicolumn{8}{|l|}{ ERYTHROXYLACEAE } \\
\hline Erythroxylum campestre A. St.-Hil. & 8 & 19 & shrub & endo & 1 & 1 & 1 \\
\hline Erythroxylum deciduum A. St.-Hil. & & 6 & tree & endo & 0 & 1 & 0 \\
\hline Erythroxylum suberosum A. St.-Hil. & & 8 & tree & endo & 1 & 0 & 1 \\
\hline \multicolumn{8}{|l|}{ EUPHOBIACEAE } \\
\hline Croton antisyphiliticus Mart. & & 24 & shrub & syn & 0 & 1 & 1 \\
\hline Croton glandulosus $\mathrm{L}$. & & 1 & shrub & syn & 0 & 0 & 1 \\
\hline Croton lundianus (Didr.) Müll. Arg. & & 2 & shrub & syn & 0 & 0 & 1 \\
\hline Croton pohlianus Müll. Arg. & 1 & 1 & shrub & syn & 0 & 1 & 1 \\
\hline Croton sclerocalyx (Didr.) Müll. Arg. & & 3 & shrub & syn & 0 & 1 & 1 \\
\hline Sebastiania bidentata (Mart. \& Zucc.) J. Paxon & & 1 & shrub & endo & 1 & 0 & 0 \\
\hline \multicolumn{8}{|l|}{ FABACEAE } \\
\hline Acosmium subelegans (Mohlenbr.) Yakovlev & 60 & 28 & tree & ane & 1 & 1 & 0 \\
\hline Andira laurifolia Benth. & 57 & & shrub & endo & 0 & 0 & 1 \\
\hline Camptosema ellipticum (Desv.) Burkart & & 2 & shrub & aut & 1 & 0 & 0 \\
\hline Chamaecrista flexuosa (L.) Greene & & 1 & shrub & aut & 1 & 0 & 0 \\
\hline Chamaecrista nictitans (L.) Moench & & 2 & shrub & aut & 1 & 0 & 0 \\
\hline Eriosema crinitum (Kunth.) G. Don & & 3 & herb & aut & 1 & 1 & 1 \\
\hline Eriosema longifolium Benth. & & 3 & herb & aut & 1 & 0 & 0 \\
\hline Galactia decumbens (Benth.) Chodat \& Hassl. & & 9 & herb & aut & 1 & 0 & 1 \\
\hline Galactia dimorpha Burkart & 13 & 2 & herb & aut & 1 & 1 & 0 \\
\hline Galactia martii DC. & 37 & 28 & herb & aut & 0 & 1 & 1 \\
\hline Mimosa gracilis Benth. & 3 & 8 & herb & aut & 1 & 1 & 1 \\
\hline Mimosa polycephala Benth. & & 6 & shrub & aut & 1 & 1 & 0 \\
\hline Periandra mediterranea (Vell.) Taub. & & 24 & shrub & aut & 1 & 1 & 0 \\
\hline Platypodium elegans Vogel & & 4 & tree & ane & 1 & 0 & 1 \\
\hline \multicolumn{8}{|l|}{ IRIDACEAE } \\
\hline Sisyrinchium vaginatum Spreng. & 5 & 6 & herb & aut & 1 & 0 & 1 \\
\hline Trimezia juncifolia Klatt & 1 & & herb & aut & 0 & 1 & 1 \\
\hline \multicolumn{8}{|l|}{ LAMIACEAE } \\
\hline Eriope crassipes Benth. & 1 & 7 & herb & aut & 1 & 1 & 1 \\
\hline Hyptis adpressa A. St-Hill. ex Benth. & 43 & 13 & herb & aut & 0 & 0 & 1 \\
\hline Hyptis villosa Pohl ex Benth. & & 21 & herb & aut & 1 & 1 & 1 \\
\hline Hyptis virgata Benth. & & 1 & herb & aut & 1 & 1 & 1 \\
\hline Ocimum sp. & 129 & 62 & herb & aut & 1 & 1 & 1 \\
\hline Peltodon tomentosas Pohl. & 7 & & herb & aut & 1 & 1 & 1 \\
\hline \multicolumn{8}{|l|}{ LYTHRACEAE } \\
\hline Cuphea carthagenensis (Jacq.) J. F. Macbr. & 3 & 18 & herb & aut & 1 & 0 & 1 \\
\hline Cuphea linarioides Cham. \& Schltdl & 1 & & herb & aut & 0 & 0 & 1 \\
\hline Cuphea sp. & 2 & & herb & aut & 0 & 0 & 1 \\
\hline \multicolumn{8}{|l|}{ MALPIGHIACEAE } \\
\hline Byrsonima crassa Nied. & & 2 & tree & endo & 1 & 1 & 1 \\
\hline Byrsonima guilleminiana A. Juss. & & 6 & shrub & endo & 0 & 0 & 1 \\
\hline
\end{tabular}


continuation

\begin{tabular}{|c|c|c|c|c|c|c|c|}
\hline Family/Species & $\mathrm{HC}$ & $\mathrm{SC}$ & GF & Disp & Late & Dry & Early \\
\hline \multicolumn{8}{|l|}{ MALVACEAE } \\
\hline Byttneria oblongata Pohl & 14 & 22 & herb & aut & 1 & 1 & 0 \\
\hline Krapovickasia macrodon (DC.) Fryxell & 1 & & herb & aut & 0 & 0 & 1 \\
\hline Peltaea edouardii (Hochr.) Krapov. \& Cristóbal & 1 & 6 & herb & aut & 1 & 1 & 1 \\
\hline Waltheria douradinha A. St-Hil. & & 7 & herb & aut & - & - & - \\
\hline \multicolumn{8}{|l|}{ MELASTOMATACEAE } \\
\hline Miconia ligustroides (DC.) Naudin & & 10 & tree & endo & 0 & 1 & 1 \\
\hline \multicolumn{8}{|l|}{ MENISPERMACEAE } \\
\hline Cissampelos ovalifolia DC. & & 1 & herb & endo & 1 & 0 & 0 \\
\hline \multicolumn{8}{|l|}{ MYRTACEAE } \\
\hline Campomanesia pubescens (DC.) O. Berg & 2 & 192 & tree & endo & 0 & 0 & 1 \\
\hline Eugenia angustissima $\mathrm{O}$. Berg & 59 & 256 & shrub & endo & 0 & 1 & 1 \\
\hline Eugenia aurata O. Berg & & 6 & tree & endo & 1 & 0 & 0 \\
\hline Eugenia bimarginata DC. & & 1 & tree & endo & 1 & 0 & 0 \\
\hline Eugenia calycina Cambess. & 81 & 14 & shrub & endo & 1 & 0 & 0 \\
\hline Eugenia complicata $\mathrm{O}$. Berg & 67 & 8 & shrub & endo & 0 & 1 & 0 \\
\hline Eugenia cristaensis O. Berg & 3 & & shrub & endo & 0 & 0 & 1 \\
\hline Eugenia livida O. Berg & 1 & 3 & tree & endo & 0 & 0 & 1 \\
\hline Eugenia piauhiensis O. Berg & & 7 & tree & endo & 0 & 1 & 0 \\
\hline Eugenia punicifolia (Kunth) DC. & & 4 & tree & endo & 1 & 0 & 1 \\
\hline Myrcia guianensis (Aubl.) DC. & & 70 & tree & endo & 0 & 1 & 1 \\
\hline Myrcia rhodeosepala Kiaersk. & 8 & 30 & tree & endo & 0 & 0 & 1 \\
\hline Myrcia torta DC. & 7 & 1 & shrub & endo & 0 & 1 & 1 \\
\hline Myrcia uberavensis O. Berg & 1 & 9 & tree & endo & 0 & 0 & 1 \\
\hline Myrciaria delicatula (DC.) O. Berg & 93 & 570 & herb & endo & 1 & 0 & 0 \\
\hline Psidium australe Cambess. & 36 & 49 & shrub & endo & 1 & 0 & 0 \\
\hline Psidium cinereum Mart. ex DC. & & 9 & shrub & endo & 1 & 0 & 1 \\
\hline Psidium firmum $\mathrm{O}$. Berg & & 18 & shrub & endo & 0 & 0 & 1 \\
\hline Psidium laruotteanum Cambess. & & 30 & tree & endo & 0 & 0 & 1 \\
\hline Psidium multiflorum Cambess. & & 1 & shrub & endo & 1 & 0 & 0 \\
\hline Psidium rufum DC. & & 9 & tree & endo & 0 & 0 & 1 \\
\hline \multicolumn{8}{|l|}{ OCHNACEAE } \\
\hline Ouratea floribunda Engl. & & 13 & shrub & endo & 0 & 1 & 1 \\
\hline Ouratea nana Engl. & & 23 & shrub & endo & 0 & 0 & 1 \\
\hline Ouratea spectabilis Engl. & & 14 & tree & endo & 0 & 0 & 1 \\
\hline \multicolumn{8}{|l|}{ POACEAE } \\
\hline Andropogon bicornis L. & 8 & 5 & herb & ane & 1 & 1 & 0 \\
\hline Andropogon fastigiatus Sw. & 5 & & herb & ane & 1 & 1 & 0 \\
\hline Andropogon leucostachyus Kunth & 1219 & 3 & herb & ane & 1 & 1 & 1 \\
\hline Anthaenantiopsis perforata (Nees) Parodi & & 19 & herb & aut & 1 & 0 & 0 \\
\hline Aristida riparia Trin. & & 2 & herb & epi & 1 & 1 & 0 \\
\hline Axonopus barbigerus (Kunth.) Hitch. & 9 & 60 & herb & endo & 1 & 1 & 1 \\
\hline Axonopus derbyanus G. A. Black & 9 & 92 & herb & aut & 1 & 1 & 1 \\
\hline Brachiaria decumbens Stapf & 8 & & herb & endo & 1 & 1 & 0 \\
\hline Ctenium chapadense (Trin.) Döll. & & 1 & herb & epi & 1 & 1 & 1 \\
\hline Elionurus latiflorus (Nees ex Stend.) Hack & & 105 & herb & ane & 1 & 1 & 1 \\
\hline Elionurus muticus (Spreng.) Kuntze & & 1 & herb & ane & 1 & 0 & 0 \\
\hline Eragrostis articulata (Schrank) Nees & 2 & 5 & herb & syn & 1 & 0 & 0 \\
\hline Gymnopogon foliosus (Willd.) Nees & 9 & 14 & herb & epi & 0 & 1 & 0 \\
\hline Hyparrhenia rufa (Nees) Stapf. & 1 & 22 & herb & epi & 0 & 1 & 0 \\
\hline Ichnanthus procurrens (Nees ex Trin.) Swallen & 2 & & herb & endo & 1 & 0 & $\begin{array}{c}0 \\
\text { ontinue }\end{array}$ \\
\hline
\end{tabular}




\begin{tabular}{|c|c|c|c|c|c|c|c|}
\hline Family/Species & $\mathrm{HC}$ & $\mathrm{SC}$ & GF & Disp & Late & Dry & Early \\
\hline Leptosaccharum filiforme (Hack.) A. Camus & & 22 & herb & epi & - & - & - \\
\hline Loudetiopsis chrysothrix (Nees) Conert & 72 & 38 & herb & epi & 1 & 0 & 0 \\
\hline Melinis minutiflora P. Beauv. & 39 & 72 & herb & epi & 0 & 1 & 1 \\
\hline Panicum olyroides Kunth. & & 1 & herb & endo & 1 & 0 & 0 \\
\hline Panicum parvifolium $\mathrm{R}$. Br. & 31 & & herb & endo & - & - & - \\
\hline Panicum rudgei Roem. \& Schult. & 57 & 26 & herb & endo & 1 & 1 & 0 \\
\hline Paspalum carinatum Humb. \& Bonpl. ex Flüggé & & 19 & herb & ane & 0 & 0 & 1 \\
\hline Paspalum dedeccae Quarín & & 1 & herb & ane & 0 & 0 & 1 \\
\hline Paspalum gardnerianum Nees & & 2 & herb & ane & 1 & 1 & 0 \\
\hline Paspalum geminiflorum Steud. & 1 & & herb & ane & 1 & 0 & 0 \\
\hline Paspalum lineare Trin. & & 8 & herb & ane & - & - & - \\
\hline Paspalum pectinatum Nees ex Trin. & 8 & 11 & herb & ane & 1 & 1 & 1 \\
\hline Rynchelytrum repens (Nees) C. E. Hubb. & 1 & 14 & herb & ane & 1 & 1 & 0 \\
\hline Schizachyrium condensatum (Kunth.) Nees & 5 & & herb & ane & 1 & 0 & 0 \\
\hline Trachypogon sp. & & 13 & herb & epi & - & - & - \\
\hline Tristachya leiostachya Nees & 78 & 844 & herb & epi & 1 & 0 & 0 \\
\hline \multicolumn{8}{|l|}{ RUBIACEAE } \\
\hline Borreria suaveolens G. Mey. & & 1 & herb & aut & 1 & 0 & 1 \\
\hline Diodia schumanii Standl. ex Bacigalupo & & 1 & herb & aut & 1 & 1 & 1 \\
\hline Diodia teres Walter & & 1 & herb & aut & 1 & 0 & 0 \\
\hline Palicourea coriacea (Cham.) K. Schum. & & 5 & shrub & endo & 1 & 1 & 1 \\
\hline Palicourea rigida Kunth. & & 1 & tree & endo & 0 & 0 & 1 \\
\hline Tocoyena formosa (Cham. \& Schltdl.) K. Schum. & & 1 & tree & endo & 1 & 1 & 0 \\
\hline \multicolumn{8}{|l|}{ SALICACEAE } \\
\hline Casearia sp. & 1 & 3 & shrub & endo & 1 & 0 & 0 \\
\hline \multicolumn{8}{|l|}{$\begin{array}{l}\text { SAPINDACEAE } \\
\text { Serianiq cissoides Radlk }\end{array}$} \\
\hline Serjania cissoides Radlk. & & 1 & herb & ane & 1 & 0 & 0 \\
\hline \multicolumn{8}{|l|}{ SAPOTACEAE } \\
\hline Pradosia brevipes (Pierre) T. D. Penn. & & 10 & herb & endo & 0 & 0 & 1 \\
\hline \multicolumn{8}{|l|}{ SCROPHULARIACEAE } \\
\hline Scoparia dulcis L. & 1 & & shrub & aut & 0 & 0 & 1 \\
\hline \multicolumn{8}{|l|}{ SOLANACEAE } \\
\hline Solanum subumbellatum Vell. & & 3 & shrub & endo & 0 & 0 & 1 \\
\hline \multicolumn{8}{|l|}{ TURNERACEAE } \\
\hline Piriqueta emasensis Arbo & & 4 & herb & aut & 0 & 0 & 1 \\
\hline
\end{tabular}

cerrado, 14 species were anemochorous; 19, autochorous; 22, endozoochorous; 13, epizoochorous; and four, synzoochorous. In the seasonal cerrado, 24 species were anemochorous; 31 , autochorous; 47, endozoochorous; nine, epizoochorous; and 10, synzoochorous. Conversely, the proportion of individuals in DGs were different (figure $1, \mathrm{G}=1725.191, P<0.001$ ), with anemochory overrepresented in the hyperseasonal cerrado and endoand epizoochory, in the seasonal cerrado. In the former, 1,321 individuals were anemochorous; 273 , autochorous; 539, endozoochorous; 199, epizoochorous; and 45, synzoochorous. In the latter, 291 species were anemochorous; 377 , autochorous; 1,592 , endozoochorous;
1,028, epizoochorous; and 94, synzoochorous. We did not find any other dispersal mode, such as hidrochory, among the hyperseasonal cerrado species.

The proportion of species in FPGs were not different (figure $2, \mathrm{G}=0.913, P=0.822$ ). In the hyperseasonal cerrado, 40 species fruited in the late rainy season; 34 , in the dry season; 38 , in the early rainy season; and 13, throughout the year. In the seasonal cerrado, 70 species fruited in the late rainy season; 50 , in the dry season; 74 , in the early rainy season; and 21 , throughout the year. However, the proportion of individuals in FPGs were different (figure 2, $\mathrm{G}=488.336, P<0.001$ ), with the 'dry season' and 'whole year' groups overrepresented 

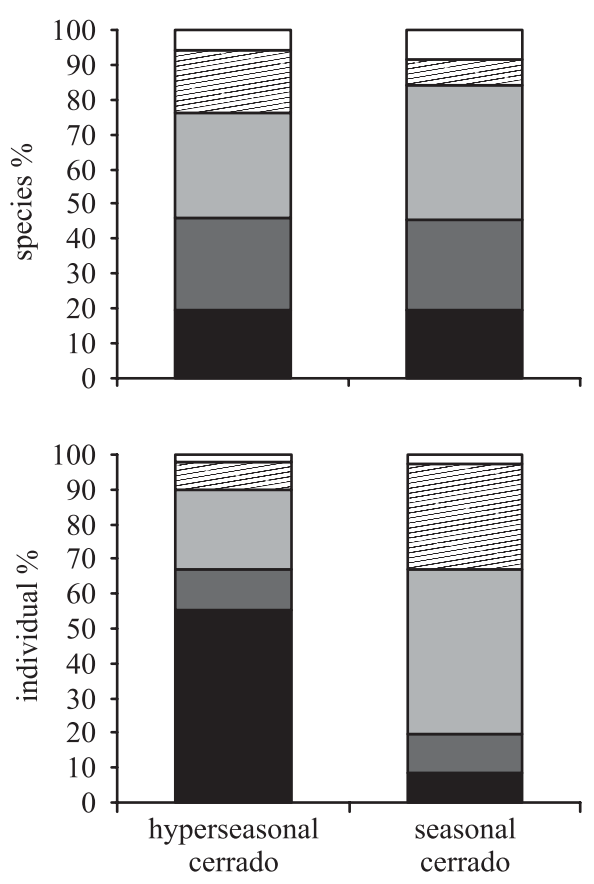

Figure 1. Percentual distribution of dispersal modes of species and individuals in the hyperseasonal cerrado and seasonal cerrado, Parque Nacional das Emas, central Brazil. ( $\square$ = anemochory; $\square=$ autochory; $\square=$ endozoochory; $\mathbb{Z}=$ epizoochory; and $\square=$ synzoochory).
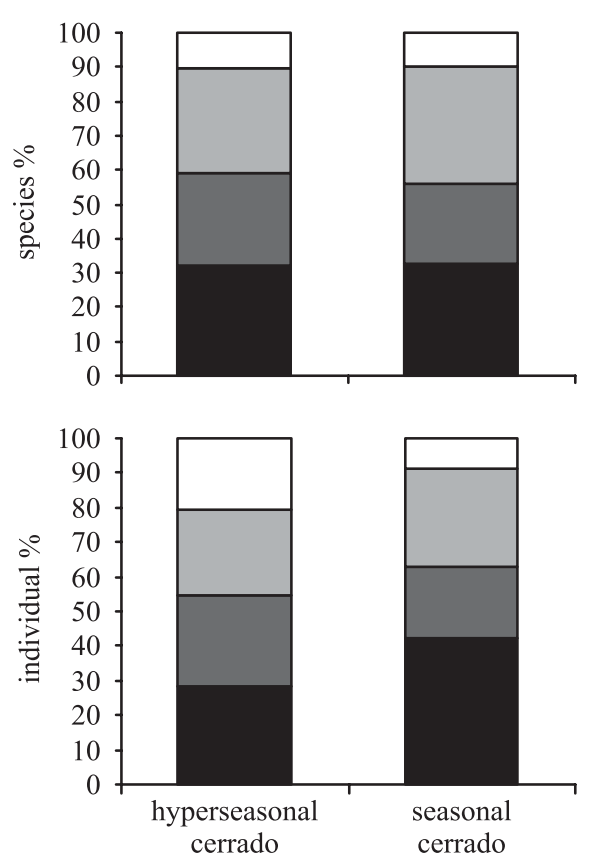

Figure 2. Percentual distribution of fruiting phenological groups of species and individuals in the hyperseasonal cerrado and seasonal cerrado, Parque Nacional das Emas, central Brazil. ( $(\square=$ late rainy season; $\square=$ dry season; $\square=$ early rainy season; and $\square=$ whole year). in the hyperseasonal cerrado and the 'early rainy season' and 'late rainy season' groups overrepresented in the seasonal cerrado. In the former, 1,992 individuals fruited in the late rainy season; 1,822 , in the dry season; 1,728 , in the early rainy season; and 1,425 , throughout the year. In the latter, 2,347 individuals fruited in the late rainy season; 1,166 , in the dry season; 1,557 , in the early rainy season; and 502, throughout the year.

\section{Discussion}

As environmental conditions constrain the survival of diaspores (Tackenberg et al. 2003, Ozinga et al. 2004), differences in the dominance of dispersal modes and fruiting periods are expected between a hyperseasonal and a seasonal cerrado. In this study, when we examined the proportion of individuals, we found that the main dispersal strategy was anemochory in the hyperseasonal cerrado and zoochory in the seasonal cerrado. We also observed that phenological strategies of fruiting in safest periods of the year were differently selected in both cerrados. We suggest that waterlogging changes the efficiency of the dispersal and phenological strategies of the hyperseasonal savanna plants.

The waterlogging did not influence the proportions of species in DGs and FPGs in the hyperseasonal cerrado. However, the waterlogging constrains the overall plant community in the hyperseasonal cerrado, as already pointed out by Cianciaruso et al. (2005) and Silva \& Batalha (2006). The hyperseasonal cerrado species are a subset of the seasonal cerrado pool, with almost half of the seasonal cerrado richness (Silva \& Batalha 2006). In general, savannas are expected to be more stable in functional than in floristic terms (Sarmiento 1996). As redundant species in each dispersal and phenological group are not entirely equivalent, they have different tolerances to environmental constraints. Consequently, changing conditions may result in a certain degree of floristic replacement, without major changes in functional groups (Sarmiento 1996). Thus, due to the high functional redundancy of cerrado plants, waterlogging changes the species richness of the hyperseasonal cerrado without affecting the distribution of dispersal and phenological functional groups.

Similar proportions of species in DG were observed in other seasonal cerrado sites (Batalha \& Mantovani 2000, Vieira et al. 2002, Gottsberger \& SilberbauerGottsberger 2006) and may be a general pattern in hyperseasonal savannas as well. Anemo- and autochorous species tend to prevail in communities with high-intensity disturbances (Ozinga et al. 2004). This generalization rests 
on the assumption that in communities with a severe disturbance regime a selective advantage is gained by those species that succeed in spreading several propagules over large parts of the landscape (Grime 2001). For example, about $70 \%$ of the Brazilian Caatinga species, a seasonally dry scrub-forest vegetation that experiences a severe drought (i.e., annual rainfall ranging from 240 to $900 \mathrm{~mm}$ ), present anemo or autochory (Tabarelli et al. 2003). Thus, the two contrasting environmental constraints, drought and waterlogging, may not be severe enough to promote changes in the proportion of species in DGs in the hyperseasonal cerrado.

On the other hand, our results indicated that the hyperseasonal cerrado environment changes the proportion of individuals in DGs and FPGs. Anemochorous species in the hyperseasonal cerrado were much more abundant than zoochorous species, whereas the opposite held true in the seasonal cerrado. Considering that the competitive ability of species is proportional to its abundance (Hutchinson 1959, Leibold 1998), the anemochorous species seem to have advantage in colonizing the hyperseasonal cerrado environment. Thus, even though waterlogging may not be severe to modify the proportion of species in DGs in the hyperseasonal cerrado, it favoured the anemochorous species.

Regarding the proportion of individuals in FPGs, the overrepresentation of the 'dry season' and 'whole year' groups in the hyperseasonal cerrado suggested that these phenological strategies were also favoured by the waterlogging. As a response to soil moisture availability, savanna plants usually reach the peak of fruiting and propagules dispersal at the rainy season, assuring reproduction in the safest period of the year (Ramirez 2002, Batalha \& Martins 2004). The overrepresentation of the 'rainy season' group in the seasonal cerrado was in accordance with this expectation. Consequently, an overall fruiting strategy of the seasonal cerrado species is escaping from drought. In the hyperseasonal cerrado, however, the water table may rise up to $20 \mathrm{~cm}$ above soil level at the end of the rainy season (Batalha et al. 2005), imposing physiological restrictions to seed establishment and plant growth (Visser et al. 2003). On the other hand, a positive consequence of waterlogging is that soil moisture availability in early dry season is higher in hyperseasonal than in seasonal savannas, assuring a safe period of establishment (Medina \& Silva 1990). Therefore, an overall phenological strategy of hyperseasonal cerrado species may be to escape from waterlogging, by promoting the establishment of diaspores able to arrive in dry season.

Finally, waterlogging may drive important modifications in the efficiency of the dispersal and phenological strategies of hyperseasonal savannas plants. Although a higher proportion of hidrochorous species has been related to wet plant communities (Ozinga et al. 2004), hidrochory does not seem be favoured in hyperseasonal savannas. Future studies should investigated the proportion of species and individuals in DGs and FPGs in other waterlogged plant communities in savanna regions, such as wet grasslands within the Cerrado domain and the esteros (sensu Sarmiento 1983) in Venezuelan savannas.

Acknowledgments - We are grateful to Fapesp, for financial support; to Capes, for the scholarship granted to I.A. Silva and M.V. Cianciaruso; to CNPq, for the financial support granted to M.A. Batalha; to Ibama, for research permission; to the "Parque Nacional das Emas" staff, for logistical assistance; to SP", UNB and IBGE herbaria; to P.K. Amorim, C.A. Casali, A.V.F. Jardim, H.F. Lima, R.A. Miotto, F. Oliveira, O.L. Silva, and M.W. Valenti, for help in field; to the taxonomists T.S. Filgueiras and R.C. Oliveira, for their assistance in the identification of species.

\section{References}

ANGIOSPERM PHYLOGENY GROUP. 2003. An update of the Angiosperm Phylogeny Group classification for the orders and families of flowering plants: APG II. Botanical Journal of the Linnean Society 141:399-436.

BATALHA, M.A. \& MANTOVANI, W. 2000. Reproductive phenological patterns of cerrado plant species at the Pé-de-Gigante Reserve (Santa Rita do Passa Quatro, SP, Brazil): a comparison between the herbaceous and woody floras. Brazilian Journal of Biology 60:129-145.

BATALHA, M.A. \& MARTINS, F.R. 2004. Reproductive phenology of the cerrado plant community in Emas National Park (Central Brazil). Australian Journal of Botany 52:149-161.

BATALHA, M.A., CIANCIARUSO, M.V., SILVA, I.A. \& DELITTI, W.B. C. 2005. Hyperseasonal cerrado, a new Brazilian vegetation form. Brazilian Journal of Biology 65:735-738.

CIANCIARUSO, M.V., BATALHA, M.A. \& SILVA, I.A. 2005. Seasonal variation of a hyperseasonal cerrado in Emas National Park, central Brazil. Flora 200:345-353.

CORNELISSEN, J.H.C., LAVOREL, S., GARNIER, E., DÍAZ, S., BUCHMANN, N., GURBICH, D.E., REICH, P.B., STEEGE, H., MORGAN, H.D., HEIJDEN VAN DER, M.G.A., PAUSAS, J.G. \& POOTER, H. 2003. A handbook of protocols for standardized and easy measurement of plant functional trait worldwide. Australian Journal of Botany 51:335-380.

GOTTSBERGER, G. \& SILBERBAUER-GOTTSBERGER, I. 2006. Life in the cerrado: a South American tropical seasonal vegetation. Vol. 2. Pollination and seed dispersion. Reta Verlag, Ulm. 
GRIME, J.P. 2001. Plant strategies, vegetation processes, and ecosystem properties. $2^{\text {nd }}$ ed., John Wiley and Sons, Chichester.

HUANG, S., GREENWAY, H. \& COLMER, T.D. 2003. Responses by coleoptiles of intact rice seedlings to anoxia: $\mathrm{K}+$ net uptake from the external solution and translocation from the caryopses. Annals of Botany 91:271-278.

HUTCHINSON, G.E. 1959. Homage to Santa Rosalia, or why there are so many kinds of animals? American Naturalist 93:145-159.

JACKSON, M.B. \& DREW, M.C. 1984. Effects of flooding on growth and metabolism of herbaceous plants. In Flooding and plant growth. (T.T. Koslowski, ed.). Academic Press, San Francisco, p.47-128.

KIER, G., MUTKE, J., DINERSTEIN, E., RICKETTS, T.H., KÜPER, W., KREFT, H. \& BARTHLOTT, W. 2005. Global patterns of plant diversity and floristic knowledge. Journal of Biogeography 32:1107-1116.

LEIBOLD, M. 1998. Similarity and local coexistence of species in regional biotas. Evolutionary Ecology 12:95-100.

MALIK, A.I., COLMER, T.D., LAMBERS, H., SETTER, T.L. \& SCHORTEMEYER, M. 2002. Short-term waterlogging has long-term effects on the growth and physiology of wheat. New Phytologist 153:225-236.

MEDINA, E. \& SILVA, J. 1990. Savannas of northern South America: a steady state regulated by water-fire interactions on a background of low nutrient availability. Journal of Biogeography 17:403-413.

NATHAN, R. \& MULLER-LANDAU, H.C. 2000. Spatial patterns of seed dispersal, their determinants and consequences for recruitment. Trends in Ecology and Evolution 15:279-285.

NICOL, J.M., GANF, G.G. \& PELTON, G.A. 2003. Seed banks of a southern Australian wetland: the influence of water regime on the final floristic composition. Plant Ecology 168:191-205.

OZINGA, W.A., BEKKER, R.M., SCHAMINÉE, J.H.J. \& VAN GROENEDAEL, J.M. 2004. Dispersal potential in plant communities depends on environmental conditions. Journal of Ecology 92:767-777.

PIJL, L. VAN DER 1972. Principles of dispersion in higher plants. $2^{\text {nd }}$ ed., Springer-Verlag, Berlin.

RAMIREZ, N. 2002. Reproductive phenology, life-forms, and habitats of the Venezuelan central plain. American Journal of Botany 89:836-842.
RATTER, J.A., RIBEIRO, J.F. \& BRIDGEWATER, S. 1997. The Brazilian cerrado vegetation and threats to its biodiversity. Annals of Botany 80:223-230.

SARMIENTO, G. 1983. The savannas of tropical America. In Ecosystems of the world - tropical savannas ( $\mathrm{F}$. Bourlière, ed.). Elsevier, Amsterdam, p.245-288.

SARMIENTO, G. 1996. Biodiversity and water relations in tropical savannas. In Biodiversity and savanna ecosystem processes: a global perspective (O.T. Solbrig, E. Medina \& J.F. Silva, eds.). Springer, Berlin, p. 61-75.

SCHAIK, C.P. VAN, TERBORGH, J.W. \& WRIGHT, J. 1993. The phenology of tropical forests: adaptive significance and consequences for primary consumers. Annual Review of Ecology and Systematics 24:353-377.

SILVA, I.A. \& BATALHA, M.A. 2006. Taxonomic distinctness and diversity of a hyperseasonal savanna in central Brazil. Diversity and Distributions 12: 725-730.

SOKAL, R.R. \& ROHLF, F.J. 1995. Biometry: the principles and practice of statistics in biological research. $3^{\text {rd }}$ ed., W. H. Freeman and Company, New York.

TABARELLI, M., VICENTE, A. \& BARBOSA, D.C.A. 2003. Variation of seed dispersal spectrum of woody plants across a rainfall gradient in north-eastern Brazil. Journal of Arid Environment 53:197-210.

TACKENBERG, O., POSCHLOD, P. \& BONN, S. 2003. Assessment of wind dispersal potential in plant species. Ecological Monographs 73:191-205.

TILMAN, D. 1997. Community invasibility, recruitment limitation, and grassland biodiversity. Ecology 78: 81-92.

VARTAPETIAN, B.B., ANDREEVA, I.N., GEBEROZOVA, I.P., POLYAKOVA, L.I., MASLOVA, I.P., DOLGIKH, Y.I. \& STEPANOVA, A.Y. 2003. Functional electron microscopy in studies of plant response and adaptation to anaerobic stress. Annals of Botany 91:155-172.

VIEIRA, D.L.M., AQUINO, F.G., BRITO, M.A., FERNANDES-BULHÃO, C. \& HENRIQUES, R.P.B. 2002. Síndromes de dispersão de espécies arbustivoarbóreas em cerrado sensu stricto do Brasil Central e savanas amazônicas. Revista Brasileira de Botânica 25:215-220.

VISSER, E.J.W, VOESENEK, L.A.C.J. \& VATAPETIAN, B.B. 2003. Flooding and plant growth. Annals of Botany 91:107-109. 